\title{
LINHAS DE PENSAMENTO QUE INFLUENCIAM O ENSINO DA EDUCAÇÃOAMBIENTAL
}

CHADDAD, Flávio Roberto. Mestrando em Educação Escolar pela Faculdade de Ciências e Letras de Araraquara/SP. Endereço: Rua Benedito Pires de Almeida, n. ${ }^{\circ} 15$, Vila Rica I. Dois Córregos, SP.

CEP: 17300-000. E-mail: frchaddad@gmail.com.

OLIVEIRA, Edilson Moreira de. Doutor em Educação Escolar pela Faculdade de Ciências e Letras de Araraquara/SP. Professor da Pós-Graduação em Educação Escolar da Faculdade de Ciências e Letras de Araraquara/SP - UNESP.

\section{RESUMO}

Este trabalho verificou que o ensino da educação ambiental não escapa das grandes narrativas: Parmenídica, que influenciou o positivismo, Heraclitiana, que influenciou a dialética, bem como do discurso Sofista, que está influenciando o discurso pós-moderno. Pelo viés positivista, a educação ambiental seria consideradanaturalística, que visaria apenas a intervenções no meio ambiente natural. Para o viés pós-moderno, a educação ambiental seria uma forma de religar o homem à natureza. Essas correntes não tecem críticas internas ao sistema capitalista. Já a dialética marxista se configura como um dos únicos meios sanos de se propor uma nova educação ambiental que seja crítica ao sistema capitalista, contribuindo pra a edificação de uma nova sociedade.

Palavras-chave: Educação ambiental; Positivismo; Pós-modernidade; Marxismo.

\section{LINES OF THOUGHT THAT INFLUENCE THE TEACHING OF ENVIRONMENTAL EDUCATION}

\section{Abstract}

This study verified that the teaching of environmental education has not escaped from the great narratives: Parmenídica, which influenced positivism, Heraclitean, which influenced the dialectics, as well as the Sophist speech, which is influencing the postmodern discourse. According to the positivist bias, environmental education would be considered naturalistic, and would only aim at intervening in the natural environment. According to the post-modern bias, environmental education would be a way to reconnect man with nature. These currents do not make an internal criticism to the capitalist system. On the other hand, marxist dialectics appears as one of the only sane means of proposing a new environmental education that criticizes the capitalist system and contributes to the building of a new society.

KeYwORDs: Environmental Education; Positivism; Post-Modernity; Marxism. 


\section{INTRODUÇão}

Nesta situação caótica em que se encontra o planeta, produto do modo de produção capitalista, há no horizonte discussões que apontam que a educação ambiental, através de um viés crítico, pode ajudar a fomentar outro sistema para o mundo. Mas qual educação ambiental? Como Oliveira e Buchala (2007) pontuaram, existe um grande limite da razão instrumental, de base positivista, que tem suas origens em Parmênides, em fundamentar os processos educativos ambientais, bem como um embate entre a raiz sana da modernidade que é o marxismo e o discurso relativista e anticientífico da pós-modernidade - que se constitui um campo em disputa. É nesse cenário que emergem três diferentes processos epistemológicos refratários de três correntes de pensamento, sob os quais a educação ambiental vem sendo pensada e proposta: o positivismo, o marxismo e as pequenas narrativas da pós-modernidade, que em suma incorporou - de acordo com a lógica aristotélica - parte do discurso sofista.

Segundo Chaddad (2004), a questão epistemológica que envolve o processo de desenvolvimento sustentável no interior capitalista centra-se nas leis imutáveis, que regemo universo, onde a verdade está dada e resta a aqueles que têm o preparo da ciência descobri-la, tirar o véu da realidade, desvelá-la. Nesse sentido, esta proposta vem alicerçada na razão instrumental, conferida ao mundo pelos defensores do estabelecimento. Além da proposta instrumental para o meio ambiente ou para as práticas educativas ambientais, tem-se configurado o que vem sendo chamada de ideologia pós-moderna, que, incorporando o discurso sofista, se reveste em um sistema onde o significante tem mais importância do que o significado. Ou seja, neste discurso pósmoderno, existe uma grande irracionalidade - uma grande perda da razão - e relativismo, todos estão com a verdade: daquilo que é e daquilo que não é. Assim, pela falta de uma razão totalizante, há a fragmentação da realidade, que se torna para o discurso pós-moderno impossível de ser conhecida - o que vai ao encontro dos anseios capitalistas. Nesse aspecto, para o capitalismo o discurso pós-moderno é sempre bem-vindo, pois provoca um "entravamento" no processo de conhecimento da realidade, que a torna não inteligível - tudo o que o capitalismo precisa para se manter como ideologia e como um sistema extremamente excludente e reificador do homeme da natureza.

Assim, a partir de comentários gerais sobre esses sistemas - o positivismo, o marxismo e a pósmodernidade -, este esboço tem como objetivos traçar os fundamentos ontológicos e epistemológicos que regem uma dessas formas de interpretar a realidade, o marxismo, que se faz presente na antiguidade, já que a razão instrumental-positivista e a solfística não tem um princípio e nem uma finalidade. Além disso, buscarse-á verificar quais as possibilidades dessas narrativas fomentarem processos educativos ambientais críticos que se desdobrem, talvez, na esperança e na utopia da construção de uma realidade ambientalmente equilibrada.

\section{UM POUCO DE HISTÓRIA E FILOSOFIA: AS RAÍZES DAS} LINHAS DE PENSAMENTO QUE INFLUENCIARAM A MODERNIDADE E A PÓS-MODERNIDADE

Neste item procurar-se-á realizar uma discussão de quais são as bases filosóficas que influenciaram o modo de pensar o ser (ontologia), o conhecer (epistemologia) e o situar do homem no mundo, que trazem repercussões para os processos de ensino da educação, inclusive da educação ambiental - que é objeto deste estudo. Assim, essas respostas irão ser buscadas nos primeiros dois pensadores do logos Parmênides de Eléia e Heráclito de Éfeso -, em Platão, que, pela primeira vez, tentou resolver a contradição entre o modo de pensar desses dois pensadores, em Aristóteles que, em sua filosofia, também se posicionou a partir dessas ideias gerais e deu início à lógica - que permeou todo o modo de conhecer da modernidade - e nos sofistas, que estão influenciando decisivamente o modo de pensar o ser e o conhecimento da pósmodernidade.

Dessa forma, Parmênides de Eléia dizia que o ser é independente de todo o movimento que se via na 
natureza, que era a base do pensamento de Heráclito de Éfeso. O movimento, afirmava ele, contradizendo Heráclito, era pura ilusão dos sentidos. Por trás do movimento estava a essência do ser. A sua constituição, portanto, era real. Segundo Parmênides, a aparência sensível das coisas da natureza, o que vemos pelos sentidos, não possui realidade, não existe real e verdadeiramente, portanto Não é. Isso vai trazer para nossos dias implicações severas para a crise ou degradação ambiental que estamos ultrapassando, na medida em que o ser humano se vê externo a este mundo, já que o mundo sensível é o lugar do Não-Ser.

Segundo Nietzsche (1996), Parmênides afirmava que o ser é imóvel, pois para onde deveria ele se movimentar? Ele não poderia ser infinitamente grande ou infinitamente pequeno, pois ele é acabado, e um infinito dado por acabado é uma contradição. Assim, limitado, acabado, imóvel, em equilíbrio, em todos os pontos igualmente perfeitos como uma esfera, ele paira, mas não em um espaço, pois caso contrário este espaço seria um segundo ser. Dessa forma, só existe a Unidade eterna. Assim, segundo Chauí (1999), em seu livro "Convite à filosofia", Parmênides tornou a cosmologia impossível, ao afirmar que o pensamento verdadeiro exige identidade, a não transformação e a não contradição do ser, ou seja, prenunciou o nascimento da lógica aristotélica, que guiou a produção do conhecimento científico da modernidade - e que está se perdendo no discurso pós-moderno.

Assim, neste discurso, se constitui uma lógica em que está implícita uma ontologia: o Ser é. O processo de conhecimento - já que a verdade (aletheia) já está dada (existem as regularidades universais que guiaram o processo de conhecimento da ciência moderna), ou seja, o ser é - se faz, somente e apenas, mediante o pensamento ou pela razão. Dessa forma, para Parmênides existia uma grande diferença entre o pensar e perceber. Segundo Chauí (1999):

Parmênides dizia que percebemos a natureza na multiplicidade e na mutabilidade das coisas que se transformam umas nas outras e se tornam contrárias a si mesmas. Mas pensamos o Ser, isto é identidade, a unidade, a imutabilidade e a eternidade daquilo que é em si mesmo. Como afirmava, perceber é ver as aparências, pensar é contemplar a realidade como idêntica a si mesma. Pensar é contemplar o Ser (p.212).

Isso veio trazer sérias implicações para como pensamos a natureza - algo inferior e externo a nós seres humanos dotados de razão, portanto, destituída da razão (irracional), desvalorizada, irreal, etc. Por outro lado, toda essa maneira ontológica (cravada no Ser que é) e epistemológica (conhecemos o Ser pela razão, pois a verdade existe e não está na realidade), que se constituiu no pensamento parmenídico, veio a influenciar as práticas educativas ambientais do presente e sinalizar para a corrente não crítica da educação ambiental, em virtude de que o ser humano é excluído da natureza, não se sente parte da natureza (é externo e superior a ela, já que ela é irreal e este possui a razão), e em virtude de que a dimensão política do conhecimento é esquecida, pois se enfatizamos meios técnicos e científicos, bem como os recursos naturais, e esses métodos estão nas mãos da ciência positivista instrumental, muitas vezes ideológica, e que não representa os interesses da maioria da população.

Porém, para Heráclito de Éfeso, o mundo era um fluxo perpétuo, onde nada permanece idêntico a si mesmo, mas tudo se transforma no seu contrário. Para ele, nossa experiência percebe o mundo como se tudo fosse estável e permanente, mas o pensamento sabe que nada permanece, tudo se torna o contrário - o logos é mudança e contradição. O Ser (ontologia) em Heráclito é o mais puro vir-a-ser, se constituindo eternamente. A verdade em Heráclito de Éfeso é a pura contradição, onde nada pode ser dito e pesado - pois tudo se encontra em transformação, ou seja, em mudança. Segundo Chauí (1999), enquanto Parmênides afirmava que é a identidade do Ser imutável, Heráclito se opunha, dizendo que a realidade se resumia na sensível luta dos contrários.

Segundo a autora, Parmênides introduz a ideia de que o que contrário a si mesmo se torna o contrário do que era e não pode ser (existir), não pode ser 
pensado, nem dito por que é contraditório, e a contradição é impensável e indizível. Assim, a história da filosofia grega - que influenciou a história do mundo ocidental - não pode deixar de ser a luta entre essas duas correntes. De um lado, Parmênides, onde se afirma ontologicamente o Ser invariável e o mundo das coisas a aparência irreal. Aqui o Ser pode ser dito, pensado, existe uma verdade que está presente (a aletheia) e só conseguimos chegar até ela pela razão, pelo pensamento. E de outro lado Heráclito, onde nada pode ser dito e pensado, pois tudo são transformação e contradição.

Tentando encontrar um caminho onde pudesse acabar com essa contradição entre as duas correntes, Platão e Aristóteles formularam dois modos diferentes de pensar o Ser e o conhecimento. Assim, Platão e Aristóteles, tentando encontrar caminhos para a contradição gerada pelo movimento em Heráclito e pela imutabilidade do Ser em Parmênides, construíram seus sistemas filosóficos calcados em duas originais explicações, que praticamente dominaram a filosofia até o aparecimento de Hegel e Marx, onde Heráclito de Éfeso, com seu modo de pensar a realidade - pela luta dos contrários e pelo movimento -, foi revivido sob outras bases ontológicas e epistemológicas.

Dessa maneira, Platão criou dois mundos. O mundo sensível, que era o outro mundo, que era o falso ser, em que percebíamos tudo em movimento - mas que era diferente do Não-Ser de Parmênides - e o mundo das ideias, das formas perfeitas, que só podemos alcançar através do exercício do pensamento, utilizando - para isso - a dialética. Assim, nesse sistema se inscreve uma ontologia em que o Ser é, pode ser dito e pensado, alcançado através da dialética, sua epistemologia. Note-se aqui que a dialética Platônica é apenas a contradição entre o polo verdadeiro e o falso, portanto diferente da dialética hegeliana e marxista, que se realiza na diversidade (a verdade, unidade, é obtida, pela reflexão, na diversidade).

Portanto, tem-se aí, realizada por Platão, a unificação entre as explicações para o logos realizadas por Parmênides e Heráclito. Note-se que, aqui, privilegia - como em Parmênides - as ideias, enquanto o mundo sensível, base da filosofia de Heráclito, é encarado apenas como a sombra do mundo das ideias, oposto, em nível inferior, ou seja, negativo. Para Aristóteles não havia necessidade de criar esses dois mundos. Segundo Aristóteles, havia apenas um mundo em que existiriam as essências e as aparências. Há seres para ele que são imutáveis (entidades matemáticas) e há seres que se transformam. Ontologicamente, o Ser para Aristóteles existe e é real.

A mudança, portanto, não seria apenas ilusão, seria simo ser realizando as suas potencialidades que estavam contidas em sua essência. Assim, este filósofo procura - como Platão - dar um novo caminho para a contradição entre a filosofia de Parmênides e Heráclito e seu foco é o mundo e não as ideias platônicas. Notese que, para ele, o Ser é presente e o seu processo de conhecimento é realizado mediante um instrumento: a lógica ou analítica. Essa é a grande diferença entre a epistemologia de Platão e Aristóteles. Enquanto aquele utiliza a dialética, que é o exercício direto do pensamento e da linguagem, este cria um instrumento, um antecessor ao próprio pensamento.

Segundo Chauí(1999, p.186), Aristóteles postulava que em todo pensamento e todo juízo a proposição está submetida aos três princípios lógicos fundamentais, condições de toda a verdade - que são as regras da metafísica:

1. Princípio da identidade: um seré sempre idêntico a si mesmo: Aé A;

2. Princípio da não contradição: é impossível que um ser seja e não seja idêntico a si mesmo ao mesmo tempo e na mesma relação. É impossível Aé Ae nãoA;

3. Princípio do terceiro excluído: dadas duas proposições com o mesmo sujeito e o mesmo predicado, uma afirmativa e outra negativa, uma delas é verdadeira e a outra, necessariamente falsa, Aé x ou não-X, não havendo terceira possibilidade.

Quanto a esta lógica formal, ou princípios da metafísica, é necessário fazer alguns apontamentos, que também serão feitos mais à frente, com o decorrer do texto. Esses apontamentos versam sobre a necessidade da lógica formal em fornecer os subsídios para o 
conhecimento disciplinar e a relação do conhecimento disciplinar com o interdisciplinar, que envolve o objeto de estudo deste trabalho, ou seja, o ensino da educação ambiental.

Nessa perspectiva, Oliveira e Buchala (2005) afirmam que não se pode prescindir de um grande desenvolvimento disciplinar na pesquisa em educação ambiental, pois sem uma sólida base disciplinar, o interdisciplinar - exigido pela lógica dialética - vira um discurso vazio. E esse conhecimento disciplinar, portanto, tem suas bases fundamentadas na lógica formal de Aristóteles, conforme afirmam:

Em sintonia com o pensamento do autor, concordamos com suas reflexões acerca da necessidade de um anterior desenvolvimento disciplinar da pesquisa ambiental, em face ao trabalho interdisciplinar, uma vezque, semuma sólida base disciplinar, o interdisciplinar vira um discurso vazio, culminando com a necessidade de que a discussão sobre a questão ambiental se estabeleça, em um primeiro momento, em sólidas bases disciplinares, a partir das quais, posteriormente, esse cabedal de conhecimento se traduza em matériaprima para posteriores integrações interdisciplinares, ressaltando assim um aspecto evidenciado pelo autor, ou seja, "o interdisciplinar alimentando-se do disciplinar". Nesta perspectiva, observamos que, em nosso trabalho educativo, devemos em consideração os argumentos do autor, uma vez que o campo da produção disciplinar do conhecimento, pelas ciências, é demarcado por uma estruturação e organização estruturada a partir da lógica formal aristotélica, que dá sustentação às pesquisas que constituem o arsenal do conhecimento científico (p.17).

Assim, os autores enfatizam a importância de se articular o conhecimento disciplinar com o conhecimento interdisciplinar, a lógica formal com a lógica dialética que eles enfatizam ao final do texto.

Além desses filósofos, que influenciaram diretamente o modo de pensar da humanidade, principalmente, na modernidade, outro grupo de filósofos, que tem como principal representante Protágoras de Abdera, vem influenciando o modo de pensar a pós-modernidade, em todos os sentidos - os sofistas. Esses filósofos enfatizam um discurso que se mostra plural e diverso, onde não se busca um sentido de verdade universal, o significado, mas cultiva-se o significante, enfatizam-se, portanto, as pequenas narrativas moleculares, os desenhos, as linguagens em vantagem das metanarrativas. Essa postura é extremamente irracional e relativista, pois se afirma que todo discurso é passível de uma verdade e a realidade é impossível de ser conhecida. Assim, trata-se, portanto, do discurso sofista, em que homem - como proferiu Protágoras - é a medida de todas as coisas e vem influenciando o discurso da pós-modernidade. Dessa forma, aqui existe uma pluralidade de discursos, onde todos têm sua cota de verdade. $O$ ser se mostra plural, diverso. A verdade se mostra relativa e se espalha o sob o véu do irracionalismo.

Segundo o metafísico Russell (2001), no século V - antes de Cristo - surgem pessoas que se achavam, em certo sentido, à margem da filosofia: eram os sofistas. Sócrates dizia que os sofistas faziam o discurso mais fraco parecer o mais forte, eram mestres na retórica, eram, portanto, hábeis nas palavras, não importando para eles a questão da verdade, que Sócrates sempre cultivou. Ainda, conforme este autor, as teorias conflitantes dos filósofos - aqui se entende Parmênides e Heráclito - não davam esperança de que fosse possível qualquer conhecimento. Aliado a esse fato, o contato com outras nações demonstrava que havia fossos intransponíveis entre os costumes das diferentes nações. Assim, os sofistas perceberam que não era possível atingir o conhecimento - a verdade universal - e declaravam que ele não era mais importante. O resumo desse modo de pensar está inscrito na velha frase de Protágoras de Abdera: " $O$ homem é a medida de todas as coisas, do ser aquilo que é, do não ser aquilo que não é."

Segundo Chauí (2002), Protágoras dizia que o homem era a medida de todas as coisas. O homem, portanto, baseado nessa frase, é o critério da realidade - do que as coisas são e de que não são. 
Ontologicamente, a questão do ser e do não ser depende inteiramente de nossas sensações, percepções, opiniões, ideias e ações. Assim, com Protágoras não há physis, não há um ser idêntico que subjaz às aparências e pode ser universalmente conhecido por todos através do pensamento. O processo de conhecimento, por essa corrente filosófica, se faz mediante a opinião que varia no tempo e no espaço, de indivíduo para indivíduo.

Nesse sentido, para os sofistas não existia um sentido universal de verdade, a verdade estava com todos e dependia de cada homem, que estava situado em determinado espaço e tempo. Dessa forma, existia como existe hoje, em virtude da contradição dos sistemas filosóficos - de Parmênides de Eléia e de Heráclito de Éfeso - e do contato com diversos povos e diferentes culturas a perda dos referenciais da racionalidade e de um sentido universal de verdade, tudo agora se torna relativo. Nesse pensamento e discurso não se cultiva verdade, mas sim a utilidade dos pontos de vista, sendo muito usado na história grega em favor, sempre, do mais forte, daquele que possui dinheiro, como afirmava o metafísico Russell (2001).

Essa maneira de pensar deu origem ao que hoje denominamos de pragmatismo. Para muitos autores, como, por exemplo, para o próprio metafísico Russell (2001), Protágoras de Abdera foi a fonte ou o pai do pragmatismo.

Hoje, como podemos notar, por um pretenso questionamento das grandes narrativas, que fincaram as suas raízes em Parmênides de Eléia e Heráclito de Éfeso - o positivismo e o marxismo -, enseja-se uma volta ao pensamento sofista, a esse modo de compreender o mundo, que contraria decisivamente os princípios da lógica aristotélica e da lógica dialética - onde o conhecimento se torna relativo e irracional, em consequência de uma pretensa emergência de uma pluralidade de atores políticos, da desvalorização do marxismo de estado, como da ciência moderna.

Esse sistema de pensamento e de conhecimento ${ }^{1}$, que não questiona o modo de produção capitalista com seu aparato político, social, religioso e ideológico, e muitos afirmam ser pós-moderno, em virtude do relativismo cultural e epistemológico que se instaurou no mundo, não deixa de ser a grande manifestação da disputa entre a manutenção do estabelecido (reprodução) com a materialização da utopia - sonho possível-, ou seja, com o processo de transformação do modo de produção capitalista em direção ao sistema socialista.

Como se deve observar, o mesmo princípio que norteia o processo de produção capitalista, em sua fase atual o neoliberalismo, que diz respeito à impossibilidade de ordenação e de planejamento do processo produtivo, norteia também o discurso pósmoderno. É nesse contexto, em que se dá ênfase ao significante, às pequenas narrativas (moleculares), à impossibilidade da ciência em abarcar a totalidade da realidade e a pretensa ideologia que desvaloriza o marxismo como possibilidade epistemológica e revolucionária, propalada até mesmos pelos meios acadêmicos, que se inscreve o discurso sofista e se reafirma plenamente, em terreno fértil, o capitalismo, com todas as suas contradições e atrocidades.

Dessa forma, este breve histórico filosófico procurou mostrar as raízes ontológicas e epistemológicas que nortearam e norteiam até nossos tempos a filosofia, tornando-se os fundamentos do pensar moderno: as duas grandes narrativas filosóficas que são o positivismo (metafísica) e o marxismo - diga-se, de passagem, inscritos na lógica aristotélica e na lógica dialética-, bem como o discurso irracional e o relativismo da pósmodernidade. Agora, o próximo item será dedicado a mostrar, sucintamente, como essas filosofias antigas influenciaram a ontologia, a epistemologia e a verdade no positivismo, no marxismo e na pós-modernidade.

\section{LiNHAS DE PENSAMENTO DA EDUCAÇÃo AMBIENTAL}

Após se discutir sucintamente as linhas de pensamentos que influenciaram a modernidade e a pós-

${ }^{1} \mathrm{O}$ sofista que se convencionou a chamar de pós-moderno. 
modernidade, bem como seus principais atores (Heráclito de Éfeso, Parmênides de Eléia, Platão, Aristóteles e Protágoras de Abdera), agora irá se buscar evidenciar o relacionamento entre a ontologia e a epistemologia em três esferas de pensamento e suas relações com o ensino da educação ambiental: o positivismo instrumental, que evolui da metafísica de Parmênides, o marxismo, o relativismo e o irracionalismo da pós-modernidade.

\section{A razão instrumental}

O que se percebe no sistema positivista é que ele se faz ou se banha na raiz parmenídica, mas não podemos dizer que há explicitamente uma ontologia, porque no positivismo radicale instrumental se perdemo princípio e a finalidade do processo de conhecimento. Mas podese afirmar que este Ser que é, ontologicamente dizendo, existe nas regularidades das leis universais aplicadas à natureza e à sociedade $\mathrm{e}$, mediante a razão e pelo método científico, cabe ao cientista trazer à luz esta verdade, que se encontra, como dizia Parmênides, encoberta pelo mundo irreal dos sentidos ou pelas sombras no caso de Platão, um nível inferior ao mundo das ideias - arquétipos perfeitos.

Trata-se, portanto, de descobri-la e desvelá-la, cabendo ao cientista - a aqueles que possuem as condições técnicas e científicas, ou seja, aqueles que detêm o conhecimento científico e que também podem manipulá-lo - trazê-la à tona. Assim, nessa perspectiva, onde existem as regularidades universais (podem ser ditas e pensadas) e a Verdade (está presente), que deve ser descoberta pelo cientista ou por um grupo de cientistas, por aqueles que detêm o método científico de conhecimento (neste caso, a metafísica), quais são as suas influências no ensino da educação ambiental?

Salvo a influência do monoteísmo judaico-cristão e da razão instrumental, que tornam a natureza externa ao ser humano, como se não tivesse nenhuma ligação com o corpo orgânico do homem, contribuindo para fomentar práticas educativas ambientais distorcidas e muitas vezes fora da realidade de cada pessoa, esta narrativa também influencia diretamente as práticas educativas ambientais, pois o que irá importar - nessa perspectiva - é a base científica e tecnológica, sob a ótica reducionista, para a utilização racionale a conservação dos recursos naturais. $\mathrm{Na}$ verdade, a prioridade são quase sempre e invariavelmente os ecossistemas e os seus recursos não humanos, deixando de lado a necessidade da construção, reconstrução de valores perdidos ou jamais alcançados pela humanidade e a atuação política coletiva - do verdadeiro promotor da situação caótica que envolve a problemática ambiental: o homem (CHADDAD; CHADDAD; GHILARDI, 2011).

Essa perspectiva foi também a encontrada por Oliveira e Buchala (2005), que, fazendo uma análise em textos de diferentes autores, constataram que, apesar de a temática ambiental abranger um todo dinâmico, no qual se incluem aspectos sociais, econômicos, históricos, culturais, éticos e estéticos, atualmente continua reduzida, no pensamento dominante, às suas dimensões naturais e técnicas. $\mathrm{Ou}$ seja, nessa perspectiva há nitidamente a elaboração de consensos nas escolas, norteados pela ótica instrumental, em parceria com uma fundamentação de matizes pragmáticos, próprios de uma abordagem equivocada dessa questão, ou seja, extremamente reducionista, inclusive demarcada pelo caráter de externalidade entre o homem com a natureza - como dito acima -, que se faz pelos sistemas antropocêntricos que erigiram há milênios.

Assim, influenciada pela perspectiva metafísica de Parmênides, calcada em uma ciência instrumental que se originou também dessa linha de pensamento, o ensino de educação ambiental, de acordo com esse viés, pressupõe práticas educativas que se radicam em concepções baseadas em um ser humano externo natureza, concepções que - como dito acima - podem ser oriundas do monoteísmo judaico-cristão, do racionalismo cientificista ou mesmo no próprio modo de conhecer da ciência moderna ${ }^{2}$. Essa concepção de

${ }^{2}$ Com exceção do marxismo. 
ensino de educação ambiental, onde a Verdade existe (regularidades naturais) e deve ser "descoberta" por aqueles que detêm o conhecimento, os cientistas ${ }^{3}$ podem excluir deliberadamente a participação popular das decisões, porque por esse viés se pode realizar a manipulação de dados científicos, portanto, a ciência torna-se inquestionável e neutra.

A ação se reduz a uma pretensa "solução" técnicacientífica promovida por um grupo de cientistas ou mesmo por um professor em sala de aula, em diversos níveis de ensino, que, ou mal intencionado ou mesmo acrítico, pode reproduzir o mesmo, muitas vezes alienado das problemáticas ambientais locais e globais. Ou seja, sem fazer uma crítica ao processo capitalista e suas consequências nefastas para o ambiente, reproduzindo a razão instrumental no processo educativo.

A educação ambiental, de uma prática social construída e construtora de humanidade, mediada pela dialética, fica reduzida à função de, por um lado, transmitir os conhecimentos técnicos e científicos, cujo eixo centralé uma ciência dura, reducionista, que define as relações homem e natureza e homem e homem e, por outro lado, de desenvolver formas eficientes de garantir a transmissão. A lógica que emerge do próprio desenvolvimento é a utilização racional desses recursos. A partir disso, a educação ambiental tem como função adaptar os indivíduos à sociedade e esses às condições limitadas do ambiente natural. Essa adaptação se faz a partir da preparação intelectual: transmissão e aquisição de conhecimentos científicos, sobretudo, reducionistas acerca do meio ambiente.

Portanto, essa educação ambiental tende a se transformar numa simples prática, voltada para a solução de um problema de forma pontual, estritamente instrumental (técnica), utilitária e desvinculada dos fatores sociais, culturais e políticos, visando apenas à mudança de comportamento e, consequentemente, sem almejar a mudança do sistema vigente - ou seja, de apenas reproduzir as condições ideais para a construção e reconstrução do sistema capitalista industrial e biotecnológico (CHADDAD; CHADDAD; GHILARDI, 2011).

Aqui, como se percebe, busca-se uma crítica ao conhecimento científico de cunho instrumental, que sem ser questionado pode representar os interesses de grupos que detêm o poder, já que a verdade só pode ser conhecida por grupos que detêm o método científico de conhecimento. Portanto, a ciência, neste caso, não é neutra ou imparcial. É dialeticamente reprodutora e transformadora - como a educação - da sociedade. Além desta crítica à ciência positiva instrumental, a questão disciplinar, refratária do conhecimento obtido com base na lógica formal e envolve este ensino de educação ambiental, também deve ser colocada. $\mathrm{Ou}$ seja, como Oliveira e Buchala (2005) afirmaram: "A lógica formal é importante para que consiga obter o conhecimento disciplinar, mas há um grande limite de sua aplicação no ensino de educação ambiental, em virtude de esta demandar uma série de fatores que não apenas os recursos naturais, o que pode reforçar ações instrumentais no processo de ensino".

Neste aspecto, deve-se articular o conhecimento disciplinar, obtido pelos instrumentos da lógica formal, com a interdisciplinaridade, senão esvaziaria o processo interdisciplinar. Esta, por sua vez, será mediada pela lógica dialética.

\section{O marxismo}

Kant foi o primeiro filósofo que separou natureza e cultura e trouxe sérios problemas para todos os filósofos posteriores. Segundo Chauí (1999), ele havia estabelecido uma distinção profunda entre a realidade em si e o conhecimento da realidade. A primeira, dizia Kant, é inalcançável por nosso entendimento, embora nossa razão aspire por ela. Para ele, apenas conhecemos o modo como a realidade se apresenta a nós (os fenômenos), organizada pela estrutura de nossa própria capacidade de conhecer, segundo o

${ }^{3}$ Sistemas estes que têm as suas origens na raiz ou veia parmenídica. 
espaço e tempo e segundo os conceitos ou categorias de nosso entendimento. Essa separação kantiana entre fenômenos e realidade em si foi interpretada por muitos filósofos como separação entre seres humanos e natureza. Um filósofo, porém, tencionando acabar com essa separação, construiu seu sistema baseado no Espírito, ou seja, que a Natureza como a Cultura fossem manifestações desse Espírito. Esse filósofo foi Hegel. E como esse Espírito se manifesta? Segundo Chauí (1999):

O movimento pelo qual o Espírito se exterioriza como Natureza e Cultura e pelo qual retorna a si mesmo como interioridade de ambas é a História, não como sequência temporal de acontecimentos e de causas e efeitos, mas como vida do Espírito. O que é o Espírito? É o verbo divino. Em grego; o logos. O que é a vida do logos (a História)? É a lógica. Que é a lógica como a vida do Espírito? É o movimento pelo qual o espírito produz o mundo (Natureza e Cultura), conhece sua produção e se reconhece como produtor - é, portanto, o movimento da atividade de criação e de autoconhecimento do Espírito. É a ciência da lógica, entendendo-se por ciência não a descrição e explicação dos fatos e de seus encadeamentos causais, mas a atividade pela qual o Espírito se conhece a si mesmo ao criar-se a si mesmo, manifestando-se ou exteriorizando-se como Natureza e Cultura. Essa ciência da lógica é a dialética (p.203).

Conforme Chauí (1999), essa dialética é totalmente diversa da dialética platônica e aristotélica, pois a verdade não está em um dos pares de termos positivos opostos. Pelo contrário, a contradição dialética nos revela um sujeito que surge e se manifesta e se transforma graças à contradição de seus predicados, tornando-se outro do que ele era pela negação interna de seus predicados - amargo e não-amargo e não amargo e doce, por exemplo.

Em lugar de a contradição ser o que destrói o sujeito (como julgavam todos os filósofos), ela é o que movimenta e transforma o sujeito, fazendo-o síntese ativa de todos os predicados postos e negados por ele. Ainda, nesse sentido, a autora pergunta: Que é a lógica, vida do Espírito? É o movimento dialético pelo qual o Espírito, como sujeito vivo, põe ou cria seus predicados, manifesta-se através deles, nega-os e os suprime como termos separados dele e diferentes dele, para fazê-los coincidirem com ele. Os predicados não são, como na lógica formal e matemática, termos positivos inertes que atribuímos ou recusamos a um sujeito, mas são realidades criadas, negadas, suprimidas e reincorporadas pelo próprio sujeito, isto é, pelo Espírito.

Porém, Marx e Engels perceberam, através da observação, que em cada modo de produção a consciência dos seres humanos se transforma e, portanto, não são as ideias, e sim as condições materiais, que movem a História. Lessa e Tonet (2011), quando tratam do idealismo e do materialismo, essências do materialismo histórico dialético, em seu livro "A filosofia de Marx", apontam as características de cada qual para a sociedade, dizendo que, para Marx, por causa do parco desenvolvimento industrial da sociedade, os filósofos e sociólogos pensavam a sociedade ou como produto da natureza ou como produto das ideias.

Marx, a partir do exame da sociedade capitalista do século XVIII, afirmou que o mundo dos homens não é só ideia e nem só matéria, mas sim uma síntese entre ideia e matéria - e que esta determina aquela. Segundo os autores, para Marx, sem a materialidade natural não poderia existir a consciência dos homens. Da mesma forma, ontologicamente o Ser Social só poderia existir como síntese das ideias com a materialidade, o que produz a sociedade humana. Conforme Chauí (1999), através dessas observações, Marx e Engels elaboraram o materialismo histórico dialético.

Com relação ao conhecimento, ou ao processo epistemológico, entre as ideias e o mundo objetivo há uma intensa mediação, que tem no trabalho a sua categoria fundante. Essa meta-narrativa ou o marxismo não é um dado posto e acabado, sua estrutura se 
constitui ontologicamente no SerSocial, o homem que se realiza na sociedade, mediante o trabalho, no labor, que ele transforma e que o transforma, bem como como disse - toda a sociedade. Esse método, portanto, parte das contradições que emanam na diversidade das relações, implicadas na sociedade, só para então - pela reflexão - se tornar uma síntese dessa diversidade dialética e possuir um caráter sinérgico e único, um sentido de Verdade que vai se construindo a partir das contradições emanadas pela realidade.

E quais as implicações dessa maneira de vislumbrar e de agir sobre o mundo proposta por Marx e Engels para o ensino da educação ambiental?

A concepção de uma educação ambiental crítica, de inspiração popular e transformadora, ou seja, marxista, está relacionada a uma concepção socioambiental de ambiente. Nessa concepção as relações homem-homem e homem-natureza não são definidas pela razão instrumental do sistema capitalista industrial e biotecnológico, mas são construídas economicamente, socialmente, politicamente e ambientalmente pelo conjunto de homens - pois, ontologicamente, no marxismo, o Ser é o Ser Social -, construção essa que também lança mão de conhecimentos científicos não reducionistas sobre a natureza como elementos importantes na construção de um novo estar da humanidade.

Pressupõe - diferentemente do que propõem o monoteísmo judaico-cristão e da razão instrumental que o homem está imbricado em seu meio ambiente. Nesse sentido, Oliveira e Buchala (2007) afirmam que é necessária uma nova definição da relação entre o humano e o não humano, e isso constitui uma prioridade, em virtude dos monismos naturalistas presentes nos discursos ambientalistas, em oposição a uma vertente culturalista. A oposição entre a natureza como reino da necessidade e da cultura como da liberdade deve ser substituída por uma visão mais completa, que mostra que o não humano não é desumano, do mesmo modo que o humano não é angelical.

Nesse sentido é que emerge um conceito de educação ambiental transformadora, em que os problemas sociais surgem da mediação dialética que os homens travam com suas realidades, onde há a superação do imediato pela incorporação deste no mediato, que se tornará a síntese de múltiplas determinações, por isso também podemos dizer que ela é socioambiental. Ou seja, o homem está inserido em seu ambiente. Não se tem aqui a distinção entre natureza e cultura, de base kantiana. Nem tampouco o monismo do corpo, onde a natureza é o referente, ou seja, o que se diz como paradigma holístico, inscrito na perspectiva teórica pós-moderna.

Assim, a participação política popular é imprescindível na construção de uma nova sociedade. Calcada nas metodologias participativas e críticas, privilegia a resolução de problemas enquanto tema gerador - pois a Verdade se constitui historicamente, não é um dado posto e acabado, o final de um percurso -, assentando-se em uma práxis transformadora, na medida em que, partindo dos fatores cotidianos e locais, de seu meio ambiente ou realidade concreta, os homens ampliam a discussão atingindo níveis cada vez mais complexos e globais de conhecimento e ação, visando, através da crítica ao sistema capitalista e aos seus aparatos ideológicos, científicos, políticos, sociais e religiosos, criar as sociedades sustentáveis (CAMPOS, 2000; GUIMARÃES, 2001; OLIVEIRA; NOVICK, 2004; CHADDAD; SILVA, 2010; CHADDAD; CHADDAD; GHILARDI, 2011).

\section{Pós-modernidade e o irracionalismo dos discursos}

Hoje, como ontem, não estamos tão longe das ideias sofistas como se pensa. Elas permanecem fruto, principalmente, da crítica à certeza da ciência e ao relativismo epistemológico que se instaurou no mundo, uma crítica ao marxismo de estado ou marxismo real, que conforme dizem não oferecem caminhos epistemológicos e revolucionários à humanidade e do desenvolvimento daquilo que muitos denominam como "a nova ciência" - que muitos querem aplicar ao sócius, à realidade e ao cotidiano, neste caso específico ao ensino da educação ambiental. Assim, esse discurso pós-moderno carrega um lastro de ceticismo e 
relativismo, bemcomo o anticientificismo até as últimas consequências, características sim do discurso sofista. Isso impede que se tenha uma apreensão da realidade em que estamos inseridos, bem como que se faça uma crítica "real" à ciência. Aqui, como bem disse Oliveira e Buchala (2007): "Não éjogar a criança com a água do banho", como querem os pós-modernos.

Assim, esse discurso pós-moderno impede, por sua ilógica lógica, que se tenha um conhecer totalizante e racional do real, que para esses adeptos da pósmodernidade deixou de ser uma referência em nossa época, em virtude do que dizem e enfatizam: da crise das grandes narrativas, a científica e a marxista.

Os sofistas defendiam qualquer posição independente se esta posição fosse ou não a verdadeira. Hoje - da mesma forma - as posições se abundam, dependendo mais do significante do que do significado que nelas está contido, ontologicamente o Ser depende do significante e a Verdade faz parte de todos os discursos, infligindo diretamente os princípios da lógica, construídos há milênios por Aristóteles e parcialmente aplicados à nossa realidade concreta, que, como lembram Oliveira e Buchala (2007), devem ser articulados, pela necessidade de nossa realidade contemporânea e da demanda do ensino de educação e de educação ambiental com a lógica dialética.

Nesse sentido, vive-se um momento em que as grandes narrativas históricas, que permearam a modernidade - a de raiz Parmenidica e a de raiz Heraclitiana -, deixaram de fazer sentido para uma parcela de cientistas e filósofos. Foram dessas duas metanarrativas que se edificaram a religião ocidental, o sistema positivista e o marxismo - que representou e ainda representa, com todas as críticas que vem recebendo nos dias de hoje pela queda do socialismo real, o grande marco de sanidade da humanidade. Além desse descrédito na raiz sana da modernidade, perfeitamente aplicável à realidade concreta, o marxismo, a evolução científica permitiu que o paradigma clássico em ciências fosse "questionado" pela emergência da física quântica e da teoria sistêmica, bem como as suas aplicações ao modo como o homem se situa na biosfera.
Essas questões, então, levaram a um descrédito mal direcionado do marxismo - como se só existisse o marxismo de Marx e seu ideal positivista e determinista - quanto da própria ciência clássica, que passou a ser alvo de críticas com base na mecânica quântica, muitas vezes infundadas, cujos postulados dessa "Nova Ciência" de forma alguma podem ser aplicados à nossas realidades como querem os defensores da pósmodernidade, ou seja, críticas que não permitem ver a ciência quântica como um produto do processo histórico que tem suas bases na ciência moderna - de Bacon, Descartes e Newton, entre outros - e que permite a esta também forma de pensar a matéria, em um nível subatômico e astronômico (espacial), ser um campo complementar a ciência moderna. Assim, para os defensores da "Nova Ciência" ou da pósmodernidade, a ciência moderna permite uma visão limitada de realidade, enquanto a mecânica quântica permite outra visão de mundo mais abrangente: o paradigma holístico. Para os defensores da pósmodernidade, nem a ciência clássica nemo marxismo podem fornecer uma visão total da realidade; no caso específico do marxismo, das contradições do sistema capitalista com seus aparatos econômicos, sociais políticos, religiosos, enfim, ideológicos, que, ao ver da pós-modernidade, já estariam superados. Para eles só há um sistema e as questões naturais devem ser solucionadas pela interação entre homem e natureza, semnenhuma crítica ao sistema de produção capitalista.

Nesse sentido, há na pós-modernidade um empobrecimento do discurso ambiental que não aponta realmente o fundamento da crise ambiental mundial: o capitalismo e seus aparatos. Nesse aspecto, para eles não é possível obter uma leitura totalizante da realidade; pelo contrário, há apenas uma multiplicidade de discursos, de realidades, de linguagens (cartografias) que fragmentam o todo e impedem que a apreensão total do real seja realizada e, portanto, a crítica e superação do sistema capitalista - esvazia-se o discurso contrário ao neoliberalismo.

Assim, onde a totalização racional no movimento de apreensão da realidade deixa de realizar, de explicar e desvelar as contradições do capitalismo, instaura-se 
o relativismo e o irracionalismo, onde o significante passa a ser mais importante que o significado, onde a educação ambiental não enfatiza o por que fazer, mas apenas o como fazer, porque se perde de vista o verdadeiro promotor dessa situação de degradação ambiental (natural e humana) que estamos atravessando - o sistema capitalista.

Portanto, sem a possibilidade de uma análise da totalidade da realidade, pela desvalorização da metanarrativa marxista e científica se instaura a crise da racionalidade, onde, por sua vez, os múltiplos discursos ou as pequenas narrativas moleculares são incapazes de não sendo ancoradas na dialética estabelecida entre burgueses e operários de transformação da realidade.

Mais uma vez, nesse aspecto, tem-se instaurado o discurso sofista, onde o homem se torna medida de todas as coisas e a verdade pertence a todos e a ninguém, como quer o capitalismo, ou seja, explodir discursos que consigam se apropriar criticamente da realidade, o que irá repercutir nos processos de ensino da educação ambiental.

Outro aspecto que está norteando o discurso da pós-modernidade, em decorrência da crítica voraz à ciência clássica, diz respeito à aplicação dos princípios epistemológicos da física quântica (que ocorre em nível subatômico, aplicados somente ao átomo) e da teoria sistêmica (discurso ecológico, ao qual Fritjof Capra está associado) ao mundo, à realidade concreta e, como não podia deixar de ser, aos processos de ensino da educação ambiental.

Esses discursos instituem a Unidade Universal e o Ecológico como princípios articuladores e estruturadores, por meio dos quais se busca interpretar ou organizar o trabalho educativo incorrendo em metáforas sistêmicas, pautadas na concepção de um universo em equilíbrio, de abrangência planetária, que conotam as relações que unem os seres humanos entre si e ao resto do mundo vivo e não vivo, importando visões genéricas da ecologia e da ciência que não problematizam os modos concretos com que os seres humanos se organizam em sociedade (OLIVEIRA; BUCHALA, 2007).

Na perspectiva de não acatar o paradigma holístico, amplamente difundo entre os que se filiam à perspectiva teórica pós-moderna, Moraes apud Oliveira e Buchala (2005) afirma que o mesmo, em nome de uma visão integrativa entre os fenômenos sociais e naturais, pode culminar emumempobrecimento e emum reducionismo significativo na análise dos processos políticos e econômicos nele imbricados. Ou seja, não sendo refratário da realidade em que estamos imersos, ou seja, o modo de produção capitalista com todos os seus aparatos ideológicos e formas de se organizar socialmente. Assim, não problematizando o ensino de educação ambiental, em seus diferentes níveis de ensino, mantém-se esse sistema com todas as suas contradições.

Por aí se vê como o discurso sofista foi incorporado em sua essência pelo capitalismo e pelo discurso pósmoderno. Conforme Oliveira e Buchala (2007), "o discurso dos críticos pós-modernos demonstra um grande desprezo pelas questões ontológicas, nutrindo-se que a história é a resultante de uma caótica avalanche de episódios, fatos e acontecimentos totalmente desconectados uns dos outros" (p.18). O que se quer é praticamente apagar a história, a visão de totalidade que esta história pode fornecer para que consigamos construir o grande rosto do capitalismo, que foi aparentemente apagado de nossa realidade pela própria construção ideológica do sistema neoliberal quanto sua desconstrução pelo discurso pós-moderno. Por isso então a crítica e a desvalorização - pelos capitalistas - ao único produto sano da modernidade: o marxismo. Este pode sim responder à altura a essa destruição do real e fazer com que as pessoas se apropriem criticamente da realidade ambiental.

\section{Considerações finais}

Podemos dizer que somos produto da história. Assim, nossas posturas epistemológicas são influenciadas pelas narrativas Parmenídica e Heraclitiana, bem como pelo discurso Sofista. Hoje, vive-se ideologicamente uma crise de referenciais, da noção de verdade, ocasionada pela crítica pós-moderna à modernidade, que reside nas formas de conhecer oriundas da ciência clássica e na dita superação do marxismo como conhecimento e ação 
revolucionária. Esses fatos, para os pós-modernos, detonam uma crise da razão e a proliferação de uma gama de discursos que têm no significante sua razão de existir e onde a postura irracionalista se perpetua. Nesse sentido, o marxismo, produto sano da modernidade e, até agora, a grande narrativa que pode oferecer um ponto de vista totalizante e racional da realidade, está sendo muito criticado em razão dos interesses do capital, que realmente querem diluir o discurso contrário aos seus anseios, de apropriação crítica da realidade e de uma formatação de um projeto político, social, econômico para a humanidade - já que, para o capitalismo, que se sustenta na ideologia pós-moderna, é impossível um projeto. Porém, como se postulou aqui, o marxismo se configura como umdos únicos meios sanos de se propor uma educação ambiental que seja crítica ao sistema capitalista e que contribua diretamente para a edificação de uma nova sociedade.

\section{REFERÊNCIAS}

CAMPOS, M.F. Educação ambiental e paradigmas de interpretação da realidade: tendências reveladas. (Tese) - Doutorado, Campinas, 2000. 389p.

CHADDAD, F.R. Formação continuada: desenvolvimento de um projeto de educação ambiental - 2002. (dissertação) -Mestrado, Campinas, 2004.

CHADDAD, F.R.; CHADDAD, M.C.; GHILARDI, R.P. Problemas e questionamentos à educação ambiental crítica. 1ed. Pará de Minas: Virtualbooks, 2011.

CHADDAD, F.R.; GHILARDI, R.Pirani. Necessidades atuais para a educação ambiental: serão possibilidades? Enciclopédia biosfera, v.6, p.1-12, 2010.

RECEBIDO EM 8/10/2014

ACEITO EM 29/10/2014
CHAUÍ, M. Convite à filosofia. São Paulo: Ática, 1999.

CHAUÍ, M. Introdução à história da filosofia: dos pré-socráticos a Aristóteles. São Paulo: Editora Companhia das Letras, 2005.

EVANGELISTA, J.E. Crise do marxismo e irracionalismo pós-moderno. 3 ed. São Paulo: Cortez, 2002.

\section{GUIMARÃES, M. A dimensão ambiental na} educação. Campinas: papirus, 2001.

HERCULANO, S.C. Do desenvolvimento (in) suportável à sociedade feliz. In: GOLDEMBERG, M. (Org.). Ecologia, ciência e política. Rio de Janeiro: Revan, 2001.

LESSA, S.; TONET, I. Introdução à filosofia de Marx. São Paulo: Expressão Popular, 2012.

NIETZSCHE, F. Parmênides de Eléia. In:_. Os pré-socráticos. São Paulo: Editora Nova Cultural, 1996.

OLIVEIRA, E.M; BUCHALA, A.S. Educação, meio ambiente e desenvolvimento humano: da crise do paradigma científico à necessidade da dialética. In: BARBOSA, Raquel LazzariLeite(Org). Formaçãode educadores - artes e técnicas - ciências e políticas.. São Paulo: Editora UNESP, 2007, v.1, p.331-351.

\section{OLIVEIRA, M.G.B; NOVICKI, V. Educação} ambiental no programa de despoluição da baia de Guanabara. Anped Sudeste. Rio de Janeiro: 02 a 06/05/2004. (CD-ROM)

RUSSEL, B. História do pensamento ocidental. Rio de Janeiro: Ediouro, 2001. 